\title{
Does Open Access Really Make Sense? A Closer Look at Chemistry, Economics, and Mathematics
}

\author{
John C. Navin and Jay Starratt
}

This article briefly reviews concepts and models associated with open access publishing. It provides a set of data about the frequency of public funding support for research published in leading journals in the disciplines of Chemistry, Economics, and Mathematics. Funding differences by discipline are highlighted. The authors' intent is not to draw broad conclusions but simply to inform the wider discussion of open access.

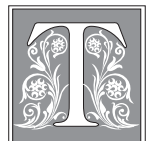

he increasing cost of scholarly publications, combined with the evolution of the Internet and the growing sophistication of search engines, has encouraged a call for journals to move to an "open access" model. In the basic model for open access publication, content is provided free on the open Internet as a replacement for the current subscription model. Currently, according to Van Orsdel and Born (2005), the publication and distribution costs of academic journals are primarily covered through subscription fees that range between a $\$ 799$ and $\$ 2,868$ average cost per title for various scientific disciplines. ${ }^{1}$ Under the most common alternative open access model, the costs of publication are derived from publication fees received from authors. McCabe and Snyder (2004) report that many online journals such as PloS Biology charge fees as high as $\$ 1,500$ per accepted article. ${ }^{2}$

Stern (2005) explores many of the alternative models of open access jour- nal pricing. BioMed Central charges no author fees to authors from member institutions. Authors from nonmember institutions pay an article processing fee of $\$ 500$. He also discusses the option of differential pricing, in which schools would pay a graduated fee based on either level of access or the types of services they demand. This model appears to be a midpoint between current subscription-based journals, where the entire costs are borne by the publisher and subscribing libraries, and open access, where the costs are borne by the authors. ${ }^{3}$ In addition to Stern, a number of studies have concentrated on the cost of both traditional paper journal publishing and electronic journals; see, for example, Willinski (2003), ${ }^{4}$ Bot, Burgemeester and Roes (1998), ${ }^{5}$ King and Tenopir (1998), ${ }^{6}$ Odlyzko (1997), ${ }^{7}$ Fisher (1997), ${ }^{8}$ Guthrie (1997), ${ }^{9}$ and Odlyzko (1994). ${ }^{10}$

While there are many models, the primary effect of moving to open access is that articles only previously available

John C. Navin is Professor, Department of Economics and Finance, and Jay Starratt is Dean of Library and Information Services, at Southern Illinois University Edwardsville; e-mail: jnavin@siue.edu and jstarra@siue.edu, respectively. 
through subscription will now be available to a larger audience through open Web access, and individuals would not be required to obtain (or have their institutions obtain) licenses for each journal they are interested in reviewing.

Why move to open access? One argument is that the movement to open access makes new research quickly available to a wider audience, thus increasing its impact. Harnad and Brody (2004) examine the impact of open access journals by looking at the differing citation rates between the articles in a traditional journal that were also available through open access with those in the journal that were not available through such means. They report that, in the physics discipline between 1992 and 2001, the ratio of open access to non-open access citations was between 2.5:1 and 5.8:1. Harnad and Brody also point out that open access allows a greater number of individuals access to journals that many libraries previously could not afford. The metric they report to measure this is the ratio of "reads" to citations in open access journals. They report that other researchers (Kurtz 2004, in particular) have found ratios of 12:1 and 17:1 for open access journals. ${ }^{11,12}$

A second argument for open access is that those who sponsor the research should have ownership of the results. In his article "Open Access in the Real World," Rick Anderson asks an important question: if funding for academic research is provided publicly through government grants or through public universities, should the information pass immediately to the public domain - should it be readily available through open access? ${ }^{13}$ This is a complicated question since, even in government supported research, there are many costs involved in publication that are borne by the entities involved in the creation and dissemination of research. There are, for instance, the costs of production of the research (facilities, collect-

\begin{tabular}{|c|c|c|}
\hline \multicolumn{3}{|c|}{$\begin{array}{c}\text { TABLE } 1 \\
\text { Journals Examined }\end{array}$} \\
\hline Name of Journal & Years & $\begin{array}{c}\text { Frequency of } \\
\text { Publishing }\end{array}$ \\
\hline \multicolumn{3}{|c|}{ Economics Journals } \\
\hline Journal of Economic Perspectives & 1999-2004 & Quarterly \\
\hline Journal of Economic Literature & 1999-2004 & Quarterly \\
\hline Quarterly Journal of Economics & 1999-2004 & Quarterly \\
\hline Brookings Papers on Economic Activity & 1999-2004 & Semi-Annually \\
\hline Journal of Political Economy & 1999-2004 & Every 2 Months \\
\hline \multicolumn{3}{|c|}{ Chemistry Journals } \\
\hline Chemical Reviews & $2000-2005$ & Monthly \\
\hline Accounts of Chemical Research & $2000-2005$ & Monthly \\
\hline Journal of the American Chemical Society & $2004-2005$ & Weekly \\
\hline \multicolumn{3}{|c|}{ Mathematics Journals } \\
\hline Bulletin of the American Mathematical Society & 1999-2004 & Quarterly \\
\hline Acta Mathematica Sinica & $2000-2004$ & Monthly \\
\hline J. Amer. Math. Soc. & 1999-2004 & Quarterly \\
\hline Comm. Pure Applied Math. & 1999-2004 & Monthly \\
\hline Inventiones Mathematica & 1999-2003 & Monthly \\
\hline
\end{tabular}




\begin{tabular}{|c|c|c|c|}
\hline \multicolumn{4}{|c|}{$\begin{array}{c}\text { TABLE } 2 \\
\text { Funding Count and Percentages by Journal and Area }\end{array}$} \\
\hline & $\begin{array}{c}\text { Total } \\
\text { Articles }\end{array}$ & $\begin{array}{l}\text { \% Funded } \\
\text { Publicly }\end{array}$ & $\begin{array}{l}\text { \% Funded } \\
\text { Privately }\end{array}$ \\
\hline \multicolumn{4}{|c|}{ Chemistry Journals } \\
\hline Chemical Reviews & 857 & 58 & 19 \\
\hline Accounts of Chemical Research & 585 & 73 & 23 \\
\hline Journal of the American Chemical Society & 4,675 & 57 & 21 \\
\hline Total/Weighted Average & 6,117 & $59 \%$ & $22 \%$ \\
\hline \multicolumn{4}{|c|}{ Economics Journals } \\
\hline Journal of Economic Perspectives & 332 & 15 & 17 \\
\hline Journal of Economic Literature & 109 & 21 & 18 \\
\hline Quarterly Journal of Economics & 236 & 50 & 42 \\
\hline Brookings Papers on Economic Activity & 78 & 14 & 14 \\
\hline Journal of Political Economy & 317 & 40 & 33 \\
\hline Total/Weighted Average & 1,072 & $31 \%$ & $32 \%$ \\
\hline \multicolumn{4}{|c|}{ Mathematics Journals } \\
\hline Bulletin of the American Mathematical Society & 259 & 14 & 4 \\
\hline Acta Mathematica Sinica & 361 & 83 & 19 \\
\hline J. Amer. Math. Soc. & 253 & 67 & 23 \\
\hline Comm. Pure Applied Math. & 298 & 63 & 21 \\
\hline Inventiones Mathematica & 369 & 58 & 21 \\
\hline Total/Weighted Average & 1,540 & $59 \%$ & $18 \%$ \\
\hline
\end{tabular}

ing and analyzing the data, and so on) and the costs of distribution (for example, assembling the journals and making them available to readers).

Even if these costs are negligible, they must be paid by someone. Under the alternative mentioned above, those costs can be easily shifted to the authors of the article. This approach makes some sense, since the authors generally reap the most direct benefits of article creation in the form of career advancement (salaries, promotion, other funding opportunities, to name a few).

Once the costs of distribution are removed from consideration, the remaining issue for the second justification for open access publishing is "who paid for the research"? This article takes a closer look at the sources of funding for published research in the three disciplines of Econom- ics, Mathematics, and Chemistry by examining the source of funding for articles appearing in some of the top journals over the past two to five years. ${ }^{14}$ The research indicates that a majority of the funding in the areas of mathematics and chemistry is publicly provided and that there is less public support for the research published in economics journals.

Table 1 lists the journals we examined and their field dates of publication and publication frequency.

Table 2 shows that in the field of chemistry we examined 4,675 different articles. Out of those, approximately 3,600 , or 59 percent, listed explicit sources of public funding for their research. Only 22 percent of the published articles listed private funding sources. In the field of economics we examined 1,072 articles between 1999 and 2004. Of those listing 
external funding, the split was about even between public and private funding -31 percent publicly funded and 32 percent privately funded. In the field of mathematics we examined 1,540 articles from five journals covering 1999-2004. Of those articles, 59 percent reported public funding, while only 18 percent reported private funding.

\section{Conclusion}

Again, we do not intend to draw broad conclusions from this investigation; the research was intended simply to provide a piece of data for the ongoing discussion. It is evident, however, that open access publishing is still establishing a clear identity and its models and methods are diverse. Increased readership, faster dissemination, and more elaborate, data-filled articles are only a few of the reasons for the interest in the approach. The case made that publicly funded research needs to be fully accessible is, at least intuitively, one of the most satisfying arguments. Clearly there is considerable public funding supporting the research published in the journals we examined. Even in our lowest publicly supported field, economics, nearly one third of the published research articles acknowledged public funding.

\section{Notes}

1. Lee C. Van Orsdel and Kathleen Born, "Choosing Sides: Periodical Price Survey 2005," Library Journal 13, no. 7 (April 15, 2005): 43-48. Available online from www.libraryjournal.com/ article/CA516819.html. [Accessed 22 May 2005].

2. Mark McCabe and Christopher M. Snyder, "The Economics of Open Access Journals," Georgia Tech Working Paper, October 22, 2004. Available online from www.prism.gatech. edu/ mm284/OA.pdf. [Accessed 17 June 2005].

3. David Stern, "Open Access or Differential Pricing for Journals: The Road Best Traveled?," Online 29, no. 2 (March/April 2005). Available online from www.infotoday.com/online/mar05/stern. shtml. [Accessed 1 June 2006].

4. John Willinsky, "Scholarly Associations and the Economic Viability of Open Access Publishing," Journal of Digital Information 4, no. 2 (Article No. 177, 2003-04-09). Available online from http://jodi.ecs.soton.ac.uk/Articles/v04/i02/Willinsky/. [Accessed 1 June 2006].

5. Marjolein Bot, Johan Bugemeester, and Hans Roes, "The Cost of Publishing an Electronic Journal: A general model and case study," D-Lib Magazine, November 1998. Available online from www.dlib.org/dlib/november98/11roes.html. [Accessed 1 April 2006].

6. Donald W. King and Carol Tenopir, "Economic Cost Models of Scientific Scholarly Journals." Working paper downloaded from www.bodley.ox.ac.uk/icsu/kingppr.htm. [Accessed 1 April 2006].

7. Andrew Odlyzko, "The Economics of Electronic Journals," The Journal of Electronic Publishing 4, no. 1 (September 1998). Available online from www.press.umich.edu/jep/04-01/odlyzko. html. [Accessed 1 April 2006].

8. Janet H. Fisher, "Comparing Electronic Journals to Print Journals: Are There Savings?" Scholarly Communication and Technology: Conference Organized by the Andrew W. Mellon Foundation at Emory University, April 24-25, 1997. Available online from www.arl.org/scomm/ scat/fisher.html. [Accessed 11 June 2006].

9. Kevin Guthrie, "JSTOR: The Development of a Cost-Driven, Value-Based Pricing Model," Scholarly Communication and Technology: Conference Organized by the Andrew W. Mellon Foundation at Emory University, April 24-25, 1997. Available online from www.arl.org/scomm/ scat/fisher.html. [Accessed 1 April 2006].

10. Andrew Odlyzyko, "Tragic Loss or Good Riddance? The Impending Demise of Traditional Scholarly Journals," Journal of Universal Computer Science (October 1994). Available online from www.jucs.org/jucs_0_0/tragic_loss_or_good/Odlyzko_A.html. [Accessed 1 April 2006].

11. Steven Harnad and Tim Brody, "Comparing the Impact of Open Access (OA) vs. Non-OA Articles in the Same Journals," D-Lib Magazine 10, no. 6 (June 2004). Available online from www. dlib.org/dlib/june04/harnad/06harnad.html. [Accessed 1 August 2005].

12. Michael J. Kurtz, "Restrictive Access Policies Cut Readership of Electronic Research Journal Articles by a Factor of Two," Harvard-Smithsonian Centre for Astrophysics, Cambridge, Mass. Available online from http://opcit.eprints.org/feb19oa/kurtz.pdf. [Accessed 30 January 2005].

13. Rick Anderson, "Open Access in the Real World: Confronting Economic and Legal Reality," 
Does Open Access Really Make Sense? 327

College and Research Library News 65, no. 4 (April 2004): 206-208. Available online from www.ala. org/ala/acrl/acrlpubs/crlnews/backissues2004/april04/openaccess.htm. [Accessed 1 June 2006].

14. The length of time varies based on the frequency of publication. For example, we use two years of data from the Journal of the American Chemical Society, which is published weekly (over 1,000 articles per year), and five years of data from the Journal of Political Economy, which is published bimonthly (about 300 articles per year)

15. Note that totals may exceed 100 percent, as some authors report multiple sources of funding (both public and private).

\section{PERRY DEAN ROGERS | PARTNERS ARCHITECTS}

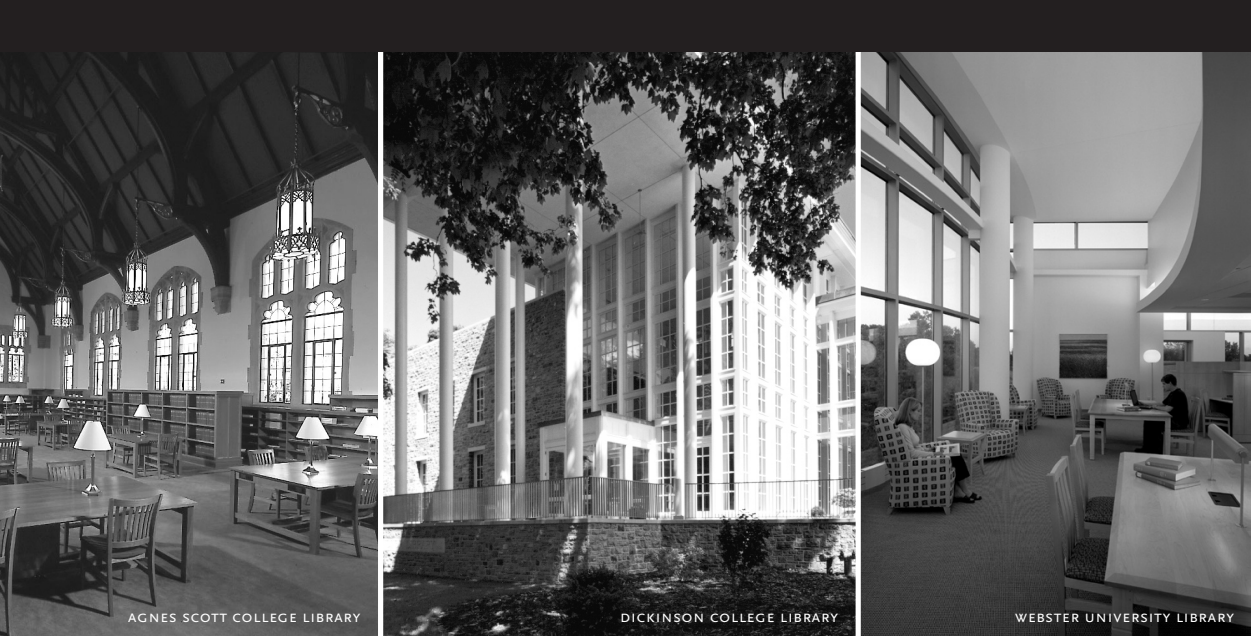

Designers for Libraries \& Academic Institutions 

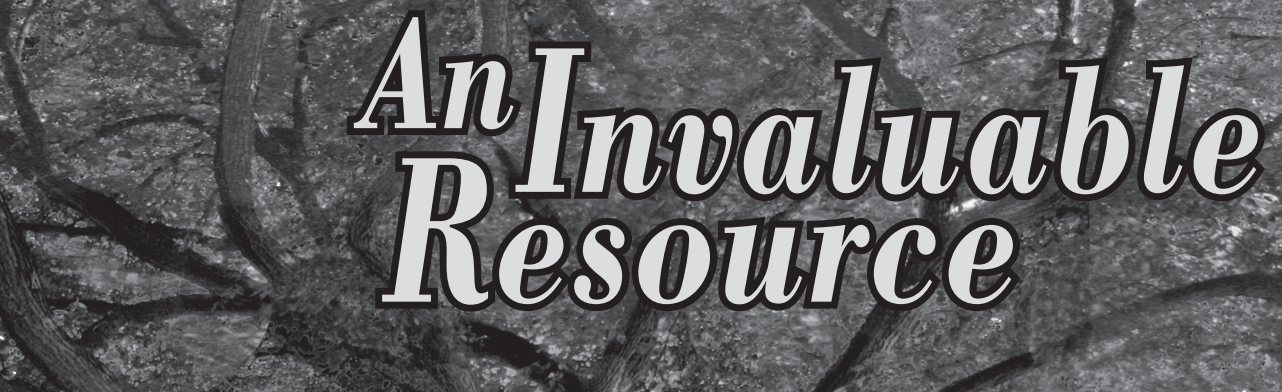

For full-text

linking capabilities, contact our online vendors. For information on the online version. please contact:

\section{CSA}

$800843-7751$

www.csa.com

\section{EBSCO Information} Services

800 653-2726

www.epnet.com

Gale Group

800 877-GALE

www.galegroup.com

OCLC

800 848-5878,

ext. 6251

www.oclc.org

\section{Proquest}

800 521-0600

www.proquest.com

For information on the print edition, please contact:

Modern Language Association 26 Broadway, 3rd floor New York, NY 10004-1789 646 576-5155 fax 646 576-5160 www.mla.org

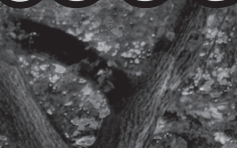

(4)

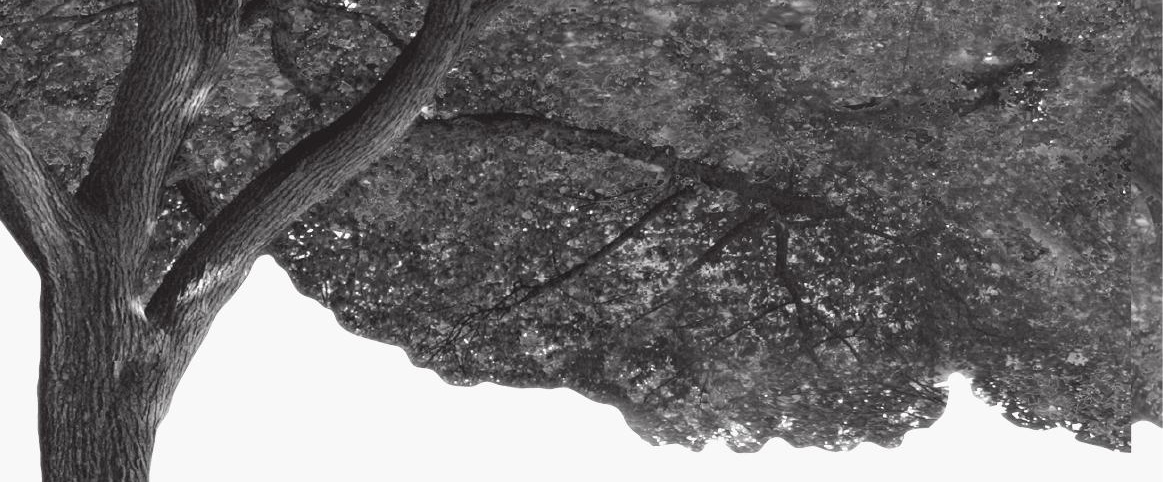

MLAA International Bibliography

The Authoritative Resource for Books and Articles on Literature, Language, Film, Linguistics, and Folklore

The bibliography's impressive database is an unparalleled research tool, offering electronic access to over 2 million citations from 1926 to the present and covering literature, language, film, linguistics, and folklore. Citations to JSTOR's language and literature and Asian Studies collections, along with over 150 electronic journals and e-books, are included.

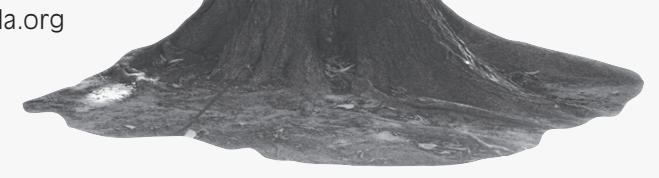

New for 2007:

Links to Project Muse full-text. 


\section{Frequently Asked Questions}

What is the MLA International Bibliography? The MLA International Bibliography is a bibliography of journal articles, books, and dissertations. It is published by the Modern Language Association, a not-for-profit organization founded in 1883 and committed to the study and teaching of language and literature.

Who uses the MLA International Bibliography? The bibliography is the research tool for college and university scholars and students. Increasingly it serves high school students and teachers and people who like to read about literature.

What material is included in the bibliography? Over 4,000 journals are regularly indexed for inclusion in the bibliography, as are books from over 1,000 publishers. scholars from universities throughout the world contribute material in their areas of expertise

Where do indexing terms come from? The Modern Language Association has drawn on the work of scholars to compile a thesaurus of over 45,000 topical terms and 327,000 names that reflect the state of current research. New concepts are regularly added to the thesaurus.

Who indexes the entries? Indexing is done by specialists with advanced degrees in literature, language, folklore, and linguistics. The bibliography's New York indexing staff has a total of 183 years' experience.

What languages are indexed? While the majority of entries are in the English language, at least 60 other languages are represented in the index, including Arabic, French, German, Italian, Japanese, Latvian, Norwegian, Portuguese, Russian, Spanish, Swedish, and Turkish. The material indexed comes from all over the globe.

\section{Scope of the MLA International Bibliography:}

` Literature from Africa, Asia, Australia,

$\nsim$ Literary theory and criticism Europe, North and South America

\% Folklore, including folk literature, music, art, rituals, and belief systems

* Linguistics and language materials, including history, theory, and translation

^ History of printing and publishing

* Dramatic arts (film, radio, television, theater)

» Teaching of literature, language, and rhetoric and composition 